privé de ses poussières flottantes. Dès lors je dois appliquer au docteur Bastian ces paroles de mon mémoire de 1862 , pages 70 et 7 I : "En présence de ces résultats (résultats que je viens de rappeler et qu'accepte le docteur Bastian), un partisan de la génération spontanée veut-il continuer à soutenir ses opinions? I1 le peut encore; mais alors son raisonnement sera forcénent celui-ci : 'Il y a dans l'air, dira-t-il, des particules solides, telles que carbonate de chaux, silice, suie, brins de laine, de coton, fécule .... et à côté, des corpuscules organisés d'une parfaite ressemblance avec les spores des mucidinées ou avec les kystes des infusoires. Eh bien, je préfère placer l'origine des mucidinées et des infusoires dans les premiers de ces corpuscles, ceux qui sont amorphes, plutôt que dans les seconds." L'inconséquence d'un pareil raisonnement ressort d'elle-même et le progrès de mes recherches consiste à y avoir acculé les partisans de l'hétérogénie. Lisez attentivement l'article précité du docteur Bastian et vous verrez qu'il se résume en effet, dans le raisonnement que je viens de reproduire. Le docteur Bastian me permettra de placer dans sa bouche ces paroles :- "C'est bien vrai, les expériences de M. Pasteur et celles de M. Tyndall m'ont acculé, moi Docteur Bastian, partisan de la génération spontanée, dans cette déclaration. Oui, je préfère recourir sans motif sérieux, à la croyance à une force résidant, dans la partie amorphe des poussières en suspension dans l'air' plutôt que de la placer cette force dans la partie organisée formée de corpuscules identiques d'aspect à ceux des germes des organismes des infusions." Parler ainsi n'est-ce pas avouer sa défaite?

Quelles sont donc ces particules amorphes dont vous invoquez si gratuitement l'influence et de quel droit leur attribuez-vous les primum movens de la vie? Pourquoi, si vous aviez raison, ne le tronverait-on pas ce primmm movens dans les particules amorphes ou organisées qui existent à l'etat naturel dans le sang frais, dans l'urine fraîche, dans le jus du raisin, quand on expose ces liquides dans l'air pur? Voulez-vous que vos particules amorphes, douées du primum movens de la vie des infusions, sortent de matières déja alterées, putrides, etc. . . . mais, pourquoi seraient-elles charićes par l'air sans être accompagnées des germes et des êtres vivants de ces infusions et, s'il en est ainsi, comment ne pas placer le primum movens de la vie dans ce qui est vivant, plutôt que dans ce qui n'a rien des caractères apparents de la vie?

Elle est inattaquable, cette conclusion que j'ai déja formuléa : dans l'état actuel de la science, l'hypothèse de la génération spontanér est une chimère.

Paris le 8 Fevrier, i 876

Votre bien dévoue

L. Pasteun

\section{Mr. Sorby on the Evolution of Hæmoglobin}

IN the short notice in NATURE (vol. xiii. p. 257) of my paper on the Evolution of Hrmoglobin, in the Quarterly Microscopical Fournal, it is said that my conclusions are mainly based on a small difference in the wave-length of the absorption-bands of the spectrum of the red blood of Planorbis. This is, however, a very small part of the question. The principal results are that hrmatin is first met with in the bile of many pulmoniferous molluscs in an abnormal state, quite unfit to serve the purposes of respiration, but easily changed into the normal, which could, and probably does in some cases, perform that function. Then in the blood of Planorbis we have a solution of a hæmoglobin, in which the hæmatin is combined with an albuminous constituent coagulating at the low temperature of $45^{\circ} \mathrm{C}$., and finally we come to the normal hrmoglobin existing as red corpscutes, containing an entirely different albuminous constituent, coagulated at about $65^{\circ} \mathrm{C}$. In all these changes in the condition of the sa me fundamental radical, the oxygen carrier becomes of more and more unstable character, and more fitted for the purposes of respiration, as we advance from lower to higher types, as though advantage had been taken of every improvement due to modified chemical or physical constitution.

H, C. SORBY

\section{The Flame of Common Salt}

IN answer to a question put by one of your correspondents ( $p$ 287), allow me to state that the origin of the blue flame in question is still involved in mystery. Your correspondent will find everything that is known on the subject in a letter addressed to the editor of the Philosophical Magazine, by Prof. J. H. Gladstone (Phil. Mag. 1862, vol. xxiv. p. 417).

Prof. Schorlemmer and $I$ are at present engaged in a joint investigation, which we hope will throw some light on the origin of the flame. We have already obtained interesting results, and observed the flame under circumstances in which it has not been seen before, but we are as yet entirely unable to say what the flame is really due to.

Owens Collega, Manchester, Feb. I2

\section{Science at Hastings}

HAD we here a few more men like Mr. Alex. E. Murray, my paper on "Science at Hastings" would never have been written. But I fail to see in what way he has "vindicated the honour of Hastings." With the exception of one or two sentences which require qualification, his letter is simply an emphatic repetition of what I said in the Hastings and St. Leonards Neres. The substance of my paper may be given in one of its sentences: "With the exception of occasional debates among the members of the Philosophical Society and the few scienuific lectures in the winter programme of the Mechanics' Institution, there is in Hastings no public encouragement or aid to science." As to the Philosophical Society, Mr. Murray admits that, "owing to a variety of circumstances, it is not at present quite so flourishing as we could wish." In point of fact, during the session 1874-75, four papers were read and a conversazione held. This Society is the only distinctively scientific one in the town, notwithstanding the "multiplicity" of institutions mentioned by Mr. Murray. Popular scientific lectures are occasionally given in connection with various associations for young men; and the Mechanics' Institution also has a winter lecture session, but un. fortunately the Committee find it very difficult to obtain lecturers, and are fain to eke out their list with musical evenings and readings. The Literary and Scientific Institution has for many years dropped the word "Scientific" from its name, and at present seeks merely to provide for a few of the older inhabitants of the town a quiet reading-room supplied with papers, a few reviews and magazines, and a box from Mudie's. Scarcely a new book has been bought for very many years. "The meteorological instruments which the Institution "formerly possessed" were, with the exception of the barometer, broken long ago, and the barometer has since been sold. At one time--twenty years ago-I was in the habit of taking the observations in the absence of the gentleman whose special business it was ; but it must be at least a dozen years since any observations were systematically taken.

In conclusion, I claim to have fully recognised in my paper all that is being done in Hastings in the interests of science, and I sincerely regret that $\mathrm{Mr}$. Murray has not been able to discover any omission on my part. We have no museum, we have no public library in which there are scientific books recent or numerous enough to be of any use to a student, except in a school or two ; we have no Naturalists' or Field Clubs; with the excep. tion of the Philosophical Society, all the existing institutions in Hastings have practically lost what scientific character they may at one time have possessed; and the Philosophical Society itself is neither exclusively scientific nor exchusively local in its aims, and is unfortunately "not quite so flourishing" as could be wished.

Hastings, Feb. 5 ARTHUR RANSOM

\section{OUR ASTRONOMTCAL COIUMN}

The VARiable StaR R LePORIS,-This highlycoloured star, the variability of which was detected by Schmidt in 1855 , is calculated to be at a maximum on the 28th of the present month. The mean period appears to be about 438 days, 230 days being occupied in passing from minimum to maximum, and 208 days from maximum to minimum. Probably the irregularities of variation which have been suspected are to be mainly attributed to the difficulty attending comparisons of a star of such intensely red colour. With regard to the colour, however, there is something more than a suspicion that it has sensibly diminished in intensity since attention was first directed to it (Hind, I845, October). We are almost wholly indebted to Schrnidt, who makes such excellent use of the favourable astronomical conditions under which he is placed at Athens, for our knowledge of the law of variation in $\mathrm{R}$ Leporis. 